\title{
Virus-like particles in Urastoma cyprinae, a turbellarian parasite of Mytilus galloprovincialis
}

\author{
C. Crespo-González, H. Rodríguez-Domínguez, M. Soto-Búa, P. Segade, R. Iglesias, \\ C. Arias-Fernández, J. M. García-Estévez*
}

Laboratorio de Parasitología Marina, Facultad de Ciencias del Mar, Universidad de Vigo, Campus As Lagoas-Marcosende s/n, 36310 Vigo (Pontevedra), Spain

\begin{abstract}
Urastoma cyprinae is a turbellarian parasite infecting the gills of several marine bivalves. We observed the presence of virus-like particles (24 to $30 \mathrm{~nm}$ in diameter; icosahedral symmetry) arranged in paracrystalline arrays in the cytoplasm of subepidermal dorsal cells. These particles appear to be RNA viruses, possibly related to the Picornaviridae. This is the first report of viral particles in the parasite U. cyprinae.
\end{abstract}

KEY WORDS: Urastoma cyprinae - Virus-like particles · Turbellaria $\cdot$ Mytilus galloprovincialis

Resale or republication not permitted without written consent of the publisher

The turbellarian Urastoma cyprinae inhabits the gills of several marine bivalves including the mussel Mytilus galloprovincialis (Fleming 1986, Robledo et al. 1994, Crespo-González et al. 2004, Rayyan et al. 2004). During the course of our investigations on the morphology of $U$. cyprinae, we detected the presence of virus-like particles (VLPs) in the cytoplasm of some subepidermal cells of adult turbellarians. The worms were isolated from the gills of the mussels M. galloprovincialis collected from the rocky intertidal zone in the south of the Vigo estuary (NW Spain), and processed for transmission electron microscopy (TEM) according to the protocol described by Bataller et al. (2003). Briefly, the worms were fixed for $2 \mathrm{~h}$ in $6 \%$ glutaraldehyde in $0.4 \mathrm{M}$ cacodylate buffer and postfixed for $2 \mathrm{~h}$ in $1 \%$ osmium tetroxide in the same buffer. The specimens were then dehydrated in increasing strength acetone series, embedded in an EponAraldite mixture and sectioned with a diamond knife using an ultramicrotome Reichert Ultracut S. The ultrathin sections were stained with uranil acetate and lead citrate prior to examination with a Philips CM20 TEM.

The VLPs are detected only in the cytoplasm of some dorsal subepidermal cells of the anterior region of the turbellarian Urastoma cyprinae (Fig. 1). They are arranged in large paracrystalline arrays that, in some cases, extended practically throughout the whole cytoplasm. The morphology of the cells containing VLPs, the electrondensity pattern of their intracytoplasmic granules, and the abundant endoplasmic reticulum observed in their cytoplasm suggest that they are probably rhabdoid cells that belong to the glandular system of $U$. cyprinae (Noury-Sraïri et al. 1990, Bataller et al. 2003). The VLPs are isometric, not enveloped, about 24 to $30 \mathrm{~nm}$ in diameter and present a typical icosahedral symmetry (Fig. 2). Some of the infected cells show several intracytoplasmic membranous vesicles (Fig. 3), which are cytopathological changes usually associated with the presence of virus (Suhy et al. 2000, Carballal et al. 2003). These vesicles have been observed before in other turbellarians infected with VLPs (Reuter 1975).

Although we have not found evidence of viral replication, the finding of cytopathological signs in cells containing VLPs, the broad cytoplasmic distribution of the particles observed in some cells, and the absence of a single phospholipid-bilayer membrane surrounding them confirm that the particles detected are in fact 

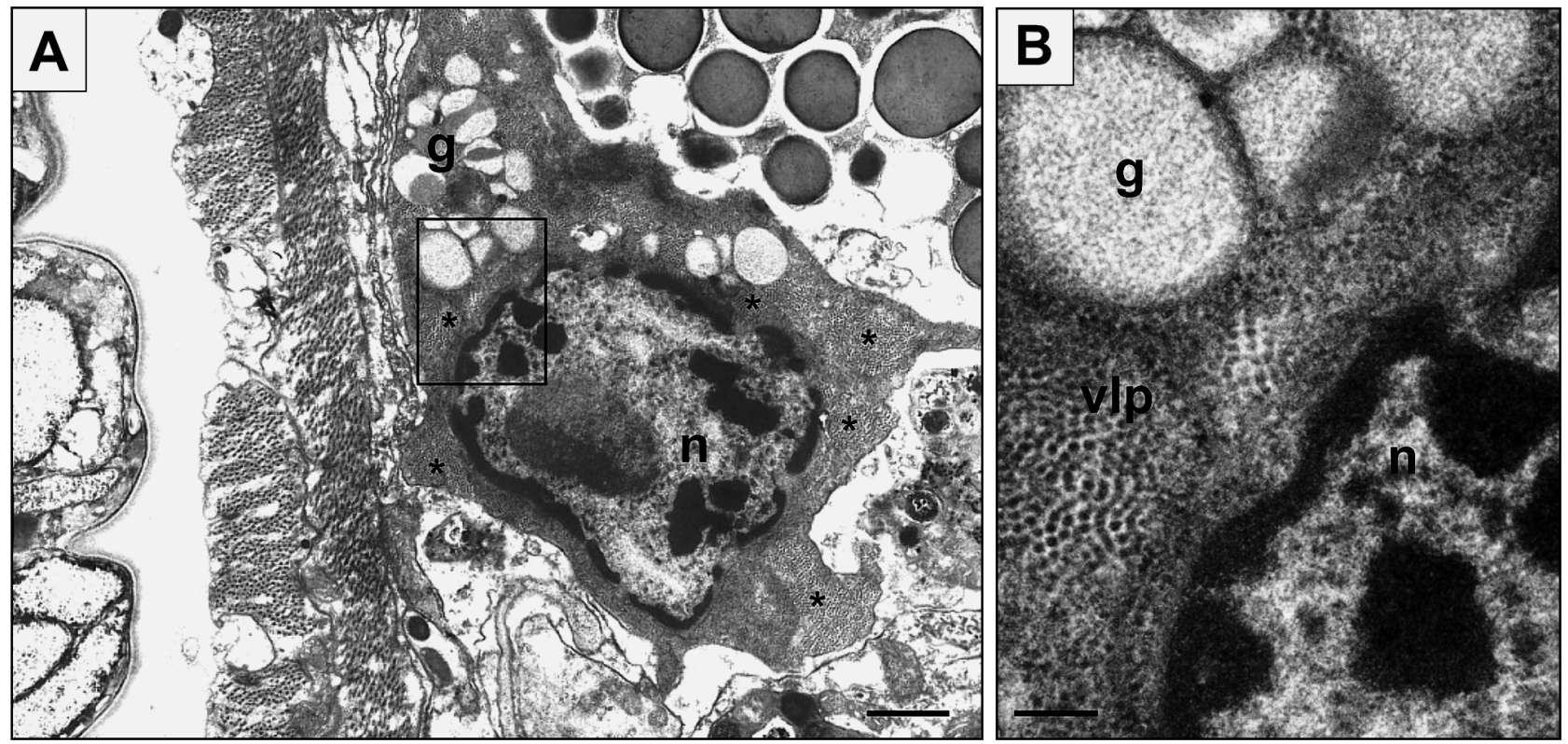

Fig. 1. Urastoma cyprinae. Transmission electron micrographs of a subepidermal cell containing numerous virus-like particles (VLPs) in the cytoplasm. (A) Infected cell at low magnification showing the VLPs (asterisks) distributed practically throughout the whole cytoplasm. Scale bar $=1 \mu \mathrm{m}$. (B) Inset of (A) at high magnification. Note the absence of viral particles in the nucleus. Scale bar $=200 \mathrm{~nm}$. g: intracytoplasmic granules; n: nucleus; vlp: virus-like particles

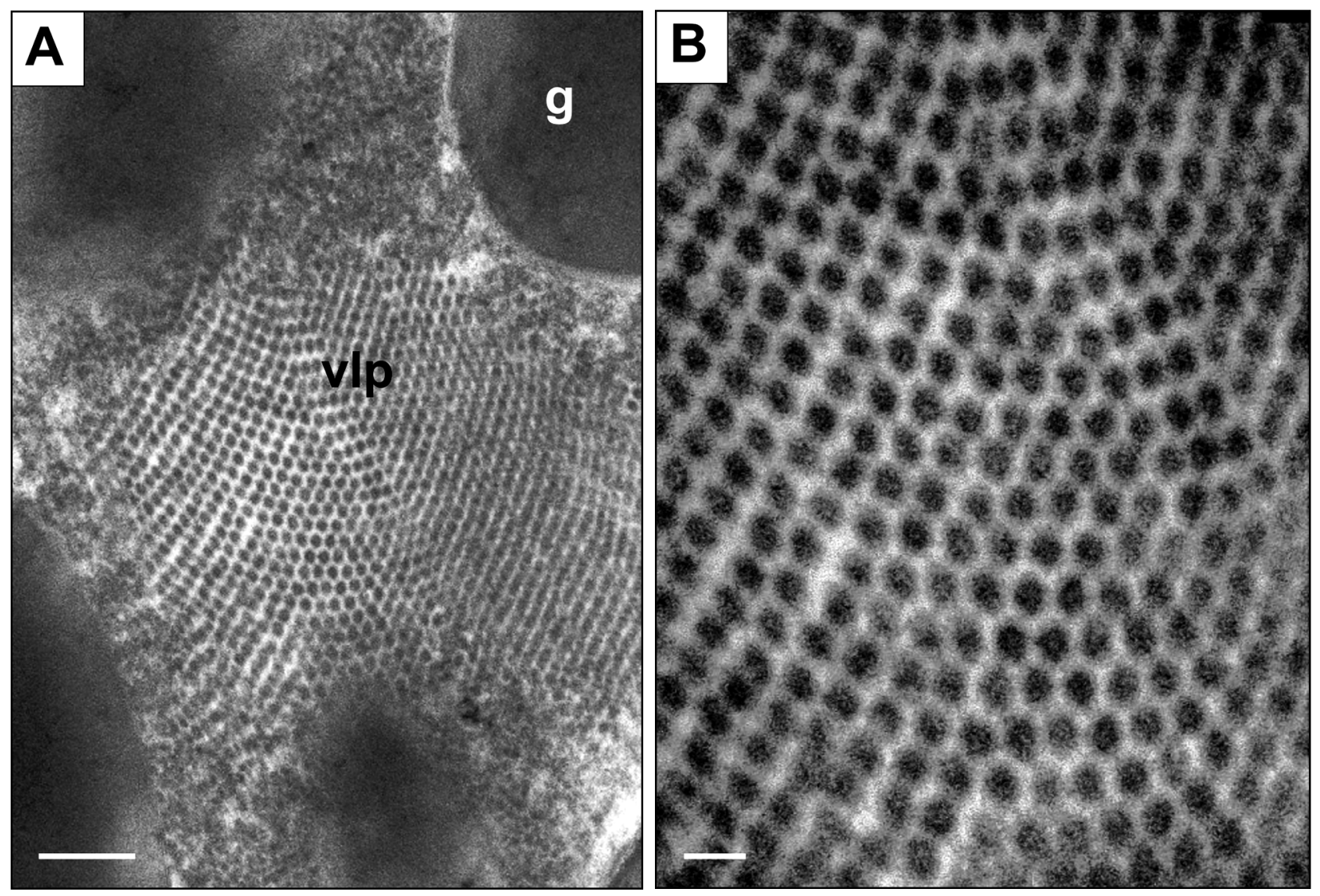

Fig. 2. Virus-like particles (VLPs) in Urastoma cyprinae. Transmission electron micrographs. (A) VLPs arranged in a paracrystalline array. Scale bar $=200 \mathrm{~nm}$. (B) Detail of the icosahedral symmetry of VLPs. Scale bar $=50 \mathrm{~nm}$. g: intracytoplasmic granules; vlp: virus-like particles 


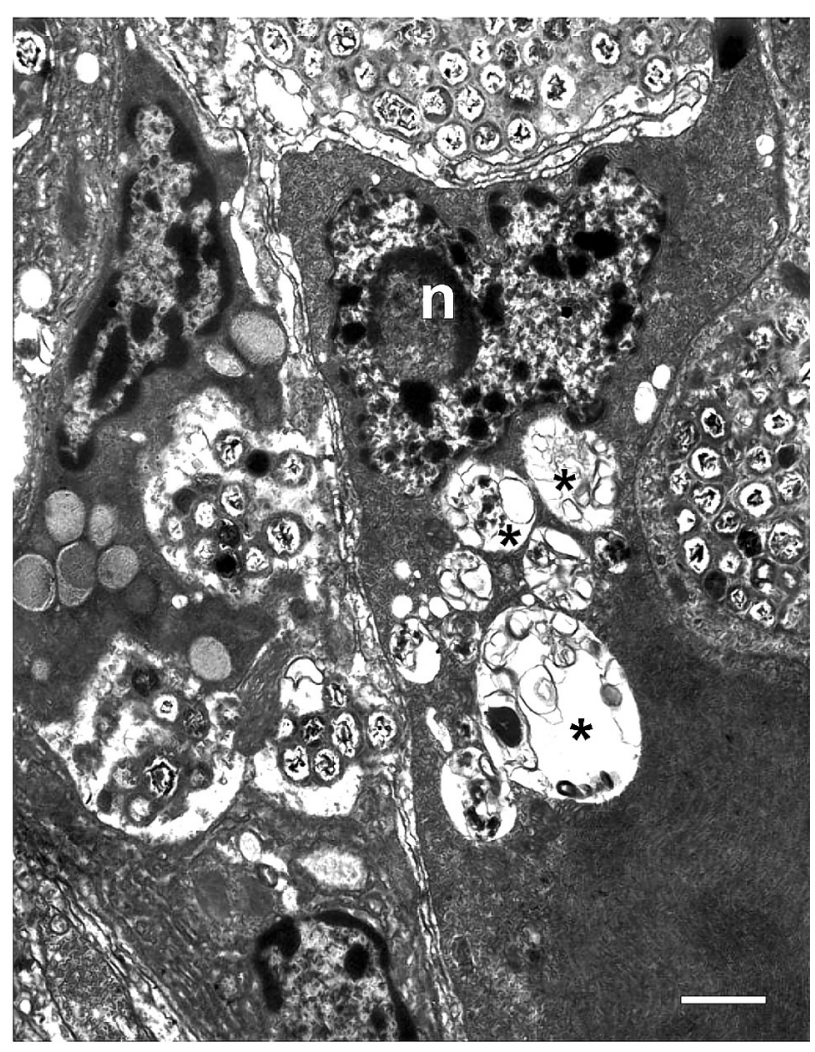

Fig. 3. Urastoma cyprinae infected with virus-like particles. Cytopathological changes associated are characterized by the presence of numerous intracytoplasmic membranous vesicles (asterisks). Scale bar $=1 \mu \mathrm{m}$. n: nucleus

viral particles and not peroxisome crystallised proteins (these organelles are small vesicles which are surrounded by a typical lipid-bilayer membrane; Michels et al. 2005). The isolation and the definitive identification of VLPs were impossible because all of the available sources had been fixed in glutaraldehyde prior to detecting the particles. However, the icosahedral symmetry, the small size, and the absence of viral particles in the nucleus of the host cells suggest that our VLPs could be RNA viruses, most likely related to the Picornaviridae. This is the first report of viral particles in Urastoma cyprinae, although infection of subtegumental cells by chlamydia-like and mycoplasm-like organisms has been previously demonstrated (Comps \& Tigé 1999). VLPs have also been detected in other freeliving and parasitic turbellarians (Oschman 1969, Reuter 1975, Justine et al. 1991, Noury-Sraïri et al. 1995) as well as in monogeneans (Justine \& Bonami 1993) and cestodes (Laclette et al. 1990). However, the icosahedral particles detected in the nuclei of the gut cells of Paravortex tapetis, a parasitic turbellarian of the digestive tract of the clam Ruditapes decussatus, by Noury-Sraïri et al. (1995), the adenovirus-like particles reported in the nuclei and the cytoplasm of proboscis gland cells and other cells of the euryhaline free-living turbellarian Gyratrix hermaphroditus by $>$ Reuter (1975), and the intranuclear VLPs found in the mucous gland cells of the turbellarian Convoluta roscoffensis by Oschman (1969) are larger (>60 nm) than the VLPs described herein.

Acknowledgements. We thank J. Méndez and I. Pazos (Centro de Apoio Científico e Tecnolóxico á Investigación; Universidad de Vigo) for technical assistance with the TEM work. This work was supported by Grant PGIDIT04RMA312002PR (Xunta de Galicia).

\section{LITERATURE CITED}

Bataller EE, Boghen AD, Burt MDB (2003) Electron and light microscopic study of various glands and the secretions released into the environment by the turbellarian Urastoma cyprinae. J Morphol 258:307-316

Carballal MJ, Villalba A, Iglesias D, Hine PM (2003) Viruslike particles associated with large foci of heavy hemocytic infiltration in cockles Cerastodesma edule from Galicia (NW Spain). J Invertebr Pathol 84:234-237

> Comps M, Tigé G (1999) Procariotic infections in the mussel Mytilus galloprovincialis and in its parasite the turbellarian Urastoma cyprinae. Dis Aquat Org 38:211-217

Crespo-González C, Reza-Álvarez RM, Rodríguez-Domínguez $\mathrm{H}$, Soto-Búa M, Iglesias $\mathrm{R}$, Arias-Fernández C, García-Estévez JM (2004) Presence of the turbellarian Urastoma cyprinae in Mytilus galloprovincialis from Vigo Estuary (NW Spain): population dynamics and effects. In: Mas-Coma S, Bargues MD, Esteban JG, Valero MA (eds) IX European Multicolloquium of Parasitology Abstracts. Valencia, p 575

$>$ Fleming LC (1986) Occurrence of symbiotic turbellarians in the oyster, Crassostrea virginica. Hydrobiologia 132: $311-315$

Justine JL, Bonami JR (1993) Virus-like particles in a monogenean (Platyhelminthes) parasitic in a marine fish. Int J Parasitol 23:69-75

Justine JL, Ponce de León R, Mattei X, Bonami JR (1991) Viral particles in Temnocephala iheringi (Platyhelminthes, Temnocephalidea), a parasite of the mollusc Pomacea canaliculata. J Invertebr Pathol 57:287-289

Laclette JP, Merchant MT, Damian RT, Willms K (1990) Crystals of virus-like particles in the metacestodes of Taenia solium and T. crassiceps. J Invertebr Pathol 56: 215-221

Michels PAM, Moyersoen J, Krazy H, Galland N, Herman M, Hannaert V (2005) Peroxisomes, glyoxysomes and glycosomes (review). Mol Membr Biol 22:133-145

Noury-Sraïri N, Justine JL, Euzet L (1990) Ultrastructure du tegument et des glandes sous-épithéliales de Urastoma cyprinae (Prolecithophora), turbellarié parasite de mollusque. Ann Sci Nat Zool 11:53-71

Noury-Sraïri N, Justine JL, Bonami JR (1995) Viral particles in a flatworm (Paravortex tapetis) parasitic in the commercial clam, Ruditapes decussatus. J Invertebr Pathol 65: 200-202

Oschman JL (1969) Endonuclear virus-like bodies in Convoluta roscoffensis (Turbellaria, Acoela). J Invertebr Pathol 13:147-148

Rayyan A, Photis G, Chintiroglou CC (2004) Metazoan para- 
site species in cultured mussel Mytilus galloprovincialis in the Thermaikos Gulf (North Aegean Sea, Greece). Dis Aquat Org 58:55-62

Reuter M (1975) Virus-like particles in Gyratrix hermaphroditus. J Invertebr Pathol 25:79-95

Robledo JAF, Cáceres-Martínez J, Sluys R, Figueras A (1994) The parasitic turbellarian Urastoma cyprinae (Platyhel-

Editorial responsibility: Albert Sparks,

Seattle, Washington, USA minthes: Urastomidae) from blue mussel Mytilus galloprovincialis in Spain: occurrence and pathology. Dis Aquat Org 18:203-210

Suhy DA, Giddings TH, Kirkegaard K (2000) Remodeling the endoplasmatic reticulum by poliovirus infection and by individual viral proteins: an autophagy-like origin for virus-induced vesicles. J Virol 74:8953-8965

Submitted: July 28, 2005; Accepted: December 13, 2007

Proofs received from author(s): February 9, 2008 